\title{
Cretaceous - Tertiary carbonate platform evolution and the age of India - Asia collision along the Ladakh Himalaya (NW India)
}

\author{
Owen R Green ${ }^{1 *}$, Michael P Searle ${ }^{1}$, Richard I Corfield ${ }^{2}$ and Richard M Corfield ${ }^{1,3}$ \\ 1 Department of Earth Sciences, University of Oxford, Oxford OX1 3PR, UK \\ 2 BP Amoco Exploration, Farburn Industrial Estate, Dyce, Aberdeen AB21 7PB, UK \\ 3 Department of Earth and Environmental Sciences, The Open University, Walton Hall, Milton Keynes, MK7 6AA, UK \\ * For correspondence, email: oweng@earth.ox.ac.uk
}

The India - Asia collision resulted in the formation and uplift of the Himalaya and enhanced uplift of the Tibetan plateau. The transition from marine to continental facies within the Indus - Yarlung Tsangpo suture zone and along the northern margin of the Indian plate provides the most accurate method of dating the closure of Tethys Ocean separating the Indian and Asian plates. The use of shallow water, carbonate platform-dwelling larger benthic foraminifera provides the means for defining 20 shallow benthic zones (SBZ) ranging from the base of the Paleocene up to the Eocene-Oligocene boundary (Serra-Kiel, et al. 1998), and is applied to Cretaceous-Tertiary rocks of the Ladakh Himalaya. Indirect methods of dating the collision such as palaeomagnetism (Zhu et al. 2005), dating the UHP metamorphism along the north margin of India (Leech et al. 2005), dating the youngest subduction-related granites along the southern margin of Asia (Weinberg and Dunlap 2000) or dating the post-orogenic Indus Molasse Group deposits within the suture zone (Aitchison et al. 2007), cannot provide such a precise or reliable age of collision. Ophiolite obduction onto the Indian passive margin occurred during the latest Cretaceous and pre-dated initial collision of the two continental plates (Corfield et al. 1999). Unconformities occur beneath the Late Maastrichtian Marpo Formation, and beneath the Danian Stumpata Formation on the shelf and beneath the Upper Paleocene Sumda Formation in the suture zone. Stratigraphic and structural data from the Indian plate continental margin in the Ladakh and Zanskar Himalaya, NW India, suggest that the final marine sediments were shallow marine limestones containing a diverse assemblage of larger benthic foraminifera (Figure 1) deposited during the planktonic zone P8/shallow benthic zone SBZ10, corresponding to the Cusian stage of the late Lower Eocene (Ypresian), 50.5 Ma. A regional unconformity across shelf and suture zone above these rocks marks the beginning of continental red-bed deposition (Chulungla and Nurla Formations). The age of the final marine sediments is similar in Waziristan (NW Pakistan) to the west, and the south Tibet region to the east, suggesting that there was no significant diachroneity along the Indus - Yarlung Tsangpo suture zone. South of the Himalaya in the Hazara syntaxis, Pakistan, the youngest marine sediments correspond to Nummulite bearing limestones of the shallow benthic zone SBZ10, and planktonic foraminifera P7 zone (52-51 Ma). The timing of closure of Neo-Tethys between India and Asia corresponds closely to the ending of subductionrelated granodiorite - granite magmatism along the Ladakh Gangdese batholith (southern, Andean-type margin of the Asian plate) and precedes the drastic slowing of the northward drift of India. Continental fluvial - deltaic red-beds unconformably overlie all marine sediments, both in the suture zone and along the north Indian plate margin.
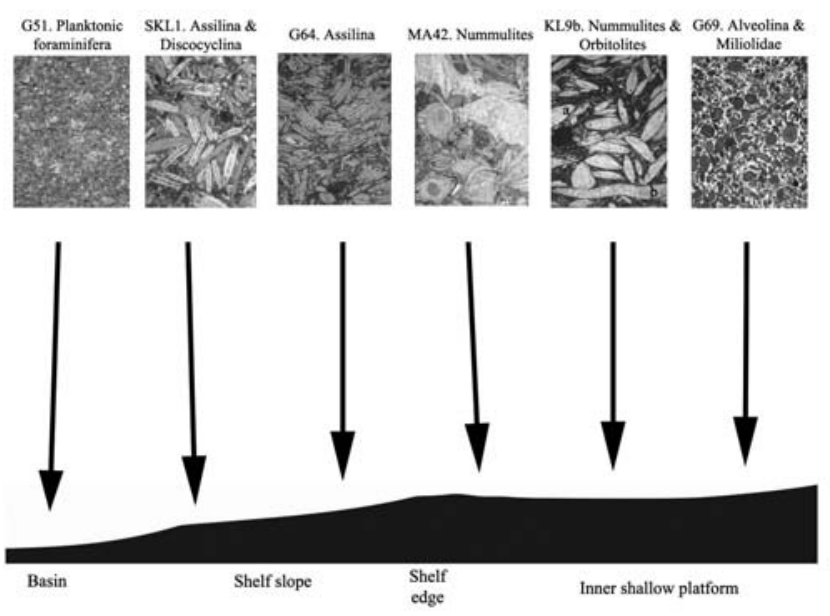

FIGURE 1. Diagrammatic reconstruction of the carbonate platform of the Cusian stage of the late Lower Eocene (Ypresian) illustrating the relative positions of the foraminiferal biofacies present along the Indian plate margin (Samples from exposures at: $G=$ Gongma, $K L=K e s i ~ L a$, $\mathrm{MA}=$ Marling, SKL = Stumpata).

\section{References}

Aitchison JC, JR Ali and AM Davis. 2007. When and where did India and Asia collide? Journal of Geophysical Research 112: doi: 10.1029/2006JB004706

CorfieldRI, MPSearle and OR Green. 1999. Photang thrust sheet: an accretionary complex structurally below the Spontang ophiolite constraining timing and tectonic environment of ophiolite obduction, Ladakh Himalaya, NW India. Journal of the Geological Society, London 156: 1031-1044

Leech ML, S Singh, AK Jain, SL Klemperer and RM Manickavasagam. 2005. The onset of India-Asia continental collision: Early, steep subduction required by the timing of UHP metamorphism in the western Himalaya. Earth and Planetary Science Letters 234: 83-97

Serra-Kiel J, L Hottinger, E. Caus, K Drobne, C Ferrández, AK Jauhri, G Less, R Pavlovec, J Pignatti, JM Samso, H Schaub, E Sirel, A Strougo, Y Tambareau, J Tosquella and E Zakrevskaya. 1998. Larger foraminiferal biostratigraphy of the Tethyan Paleocene and Eocene. Bulletin de la Societe géologique de France 169: 281-299

Weinberg RF and WJ Dunlap. 2000. Growth and deformation of the Ladakh Batholith, Northwest Himalayas; implications for timing of continental collision and origin of calc-alkaline batholiths. Journal of Geology 108: 303-320

Zhu B, SF Kidd, DB Rowley, BS Currie and N Shafique. 2005. Age of initiation of the India-Asia collision in the East-Central Himalayas. Journal of Geology 113: 265-285 